\title{
Kardiomiopatia połogowa - opis przypadku klinicznego
}

\author{
Peripartum cardiomyopathy - case report
}

\author{
Anna Maria Bednarek, Marcin Wita, Maciej Wybraniec, Katarzyna Mizia-Stec \\ I Katedra i Klinika Kardiologii Wydziału Lekarskiego Śląskiego Uniwersytetu Medycznego w Katowicach, I Oddział Kardiologii \\ Samodzielnego Publicznego Szpitala Klinicznego nr 7, Górnośląskie Centrum Medyczne im. Prof. L. Gieca
}

\section{Streszczenie}

Kardiomiopatia połogowa (PPCM) jest ostro przebiegającą postacią kardiomiopatii rozstrzeniowej, która objawia się niewydolnością serca w ostatnim miesiącu ciąży lub w ciągu 5 miesięcy od porodu. Śmiertelność opisywana w poszczególnych publikacjach waha się od 7 do 50\%. W artykule przedstawiono opis piorunującego przebiegu PPCM u 25-letniej kobiety, ze wstrząsem kardiogennym we wstępnym okresie, a następnie stopniową poprawę wymagającą kolejnych kroków diagnostycznych i terapeutycznych.

Słowa kluczowe: kardiomiopatia połogowa, ostra niewydolność krążenia, lewosimendan

Folia Cardiologica 2017; 12, 5: 489-492

\section{Wstęp}

Kardiomiopatia połogowa (PPCM, peripartum cardiomyopathy) jest postacią kardiomiopatii rozstrzeniowej objawiającej się niewydolnością serca (HF, heart failure) w ostatnim miesiącu ciąży lub w ciągu 5 miesięcy od porodu [1, 2]. W patomechanizmie PPCM uwzględnia się hiperprolaktynemię, zapalenie mięśnia sercowego, autoimmunizację wywołaną komórkami linii hematopoetycznej płodu i matki, jak również zwiększone obciążenie hemodynamiczne związane z ciążą. Wyższe stężenie prolaktyny u kobiet w okresie okołoporodowym może się przyczyniać do zwiększonego stresu oksydacyjnego skutkującego apoptozą, reakcją niedokrwienno-reperfuzyjną, co w efekcie może prowadzić do pełnoobjawowej HF [3].

Wśród czynników ryzyka PPCM wymieniono: wiek ciężarnych powyżej 30 lat, nadciśnienie tętnicze w czasie ciąży, pochodzenie afrykańskie, przedłużone stosowanie beta-mimetyków jako środków tokolitycznych, niski status socjalno-ekonomiczny. W Stanach Zjednoczonych częstość występowania PPCM wynosi 1 przypadek/1300-1500 porodów. Śmiertelność waha się od 7 do 50\%, przy czym 50\% zgonów przypada na pierwsze miesiące po rozpoznaniu [3]. Rozpoznanie PPCM powinno się uwzględniać w okresie oko- łoporodowym u pacjentek, u których występują duszność, obrzęki kończyn dolnych, zmęczenie. W badaniu klinicznym dominują nowe zjawiska osłuchowe nad sercem, zwłaszcza szmer niedomykalności mitralnej, trzeszczenia nad polami płucnymi, przepełnienie żył szyjnych oraz powiększenie wątroby. Rozstrzygająca dla rozpoznania jest ocena echokardiograficzna. W diagnostyce różnicowej należy brać pod uwagę: zawał mięśnia sercowego, posocznice, zator wodami płodowymi, zatorowość płucną, zaostrzenie HF w przebiegu nierozpoznanej kardiomiopatii rozstrzeniowej.

Rokowanie i spontaniczna odwracalność dysfunkcji lewej komory w PPCM są dużo lepsze niż w innych postaciach kardiomiopatii. Do odwracalności tej dysfunkcji najczęściej dochodzi w czasie 6 miesięcy [4]. U kobiet, u których normalizacja LVEF następuje w ciągu półrocznej obserwacji, rokowanie jest bardzo dobre, a ubytki w wydolności lewej komory pozostają minimalne [5].

\section{Opis przypadku}

Wcześniej nieleczona kardiologicznie 25-letnia kobieta została przekazana do kliniki kardiologii z oddziału położniczego w 3. dobie po porodzie siłami natury z podejrzeniem za- 
torowości płucnej. Była to pierwsza ciąża przebiegająca bez powikłań. Kardiologiczny wywiad rodzinny nie był obciążony. Przy przyjęciu pacjentka była w ciężkim stanie - wystąpiły cechy ostrej HF. W badaniu angiografii metodą tomografii komputerowej wykluczono zatorowość płucną; uwidoczniono obecność płynu w obu jamach opłucnowych (maks. do $25 \mathrm{~mm}$ ). W badaniu przedmiotowym zwracały uwage objawy lewokomorowej HF z zastojem w krążeniu płucnym oraz cechy rozwijającego się wstrząsu kardiogennego. W badaniach laboratoryjnych oznaczono wysokie stężenie $\mathrm{N}$-końcowego fragmentu propeptydu natriuretycznego typu B (NT-proBNP, N-terminal B-type natriuretic propeptide) 2422 pg/dl, nieprawidłowe stężenie troponiny - 0,081 ng/ $\mathrm{ml}$, wartość białka C-reaktywnego (CRP, C-reactive protein) $29 \mathrm{mg} / \mathrm{l}$. W badaniu echokardiograficznym stwierdzono istotnie obniżoną (do 15\%) funkcję skurczową lewej komory (LVEF, left ventricular ejection fraction), odkształcenie podłużne lewej komory (LV GLS, left ventricular global longitudinal strain) wynoszące $12,3 \%$ (ryc. 1, 2), niewielką

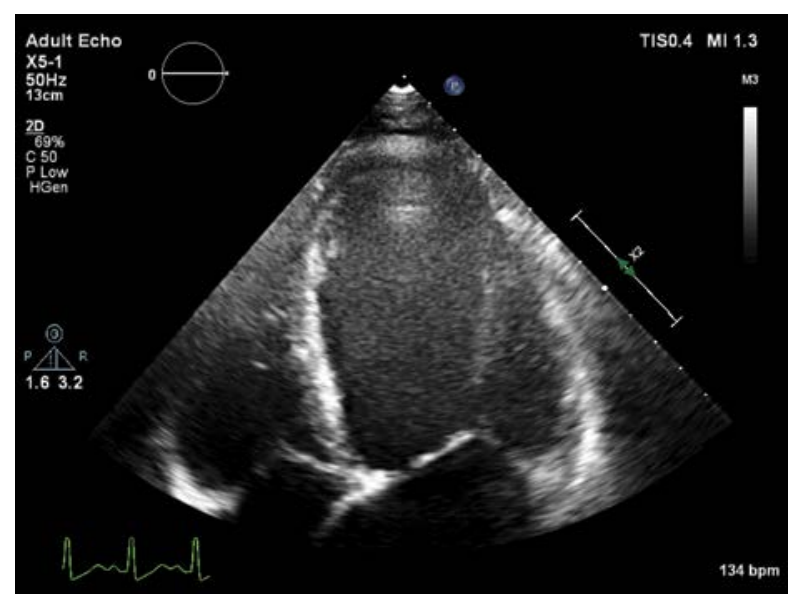

Rycina 1. Projekcja czterojamowa echokardiografii przezklatkowej - zwraca uwage powiększona lewa komora w trakcie pierwszej hospitalizacji

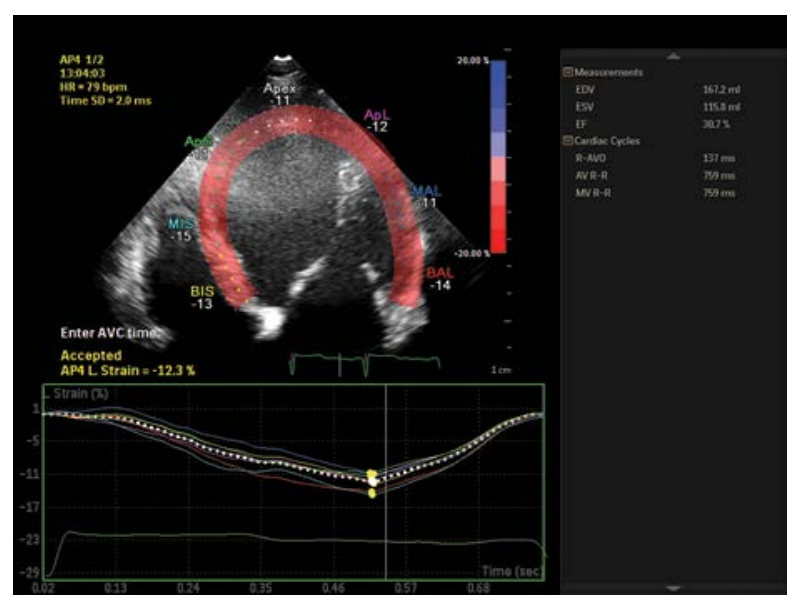

Rycina 2. Odkształcenie podłużne lewej komory (left ventricular global longitudinal strain) - ocena przy przyjęciu do szpitala rozstrzeń lewej komory (EDV, end-diastolic volume $233 \mathrm{ml}$ ), umiarkowaną niedomykalność zastawki mitralnej, nieznaczne powiększenie lewego przedsionka (powierzchnia lewego przedsionka $25 \mathrm{~cm}^{2}$ ) oraz restrykcyjny profil napływu mitralnego. W związku z klinicznymi cechami wstrząsu pacjentka wyjściowo wymagała wlewu dożylnego dobutaminy. Następnie do leczenia włączono intensywne parenteralne leczenie diuretyczne, wlew lewosimendanu, antybiotykoterapię o szerokim spektrum, profilaktykę przeciwzakrzepową heparyną drobnocząsteczkową oraz doustny preparat bromokryptyny. W wyniku zastosowanego leczenia w kolejnych dniach hospitalizacji uzyskano poprawę stanu klinicznego. W 11. dobie w monitorowaniu elektrokardiograficznym (EKG) nie obserwowano arytmii, a po zintensyfikowaniu leczenia bursztynianem metoprololu kontrola rytmu była dobra. W badaniu rezonansu magnetycznego serca wykonanym w 13. dobie hospitalizacji stwierdzono istotnie upośledzoną LVEF (20\%), znaczną rozstrzeń lewej komory oraz rozsiane linijno-plamiste ogniska późnego wzmocnienia gadolinowego (LGE, late gadolinium enhancement) i niewielkie zmiany obrzękowe, przemawiające za przewlekłym procesem zapalnym z nałożeniem świeżych zmian (ryc. 3).

Przy wypisaniu w badaniu echokardiograficznym istotnie upośledzona pozostawała LVEF 30\%, a także obecne były rozstrzeń lewej komory z EDV $273 \mathrm{ml}$ i obniżenie stężenia NTpro-BNP do 1587 pg/ml. Kolejną kontrolną hospitalizację zaplanowano 1,5 miesiąca po porodzie. Pacjentce zalecono oszczędzający tryb życia, unikanie wysiłków fizycznych, restrykcję płynową do $1500 \mathrm{ml} /$ dobę, włącznie z dalszym przyjmowaniem leków: heparyny drobnocząsteczkowej, bursztynianu metoprololu, iwabradyny, diuretyków pętlowych, bromokryptyny.

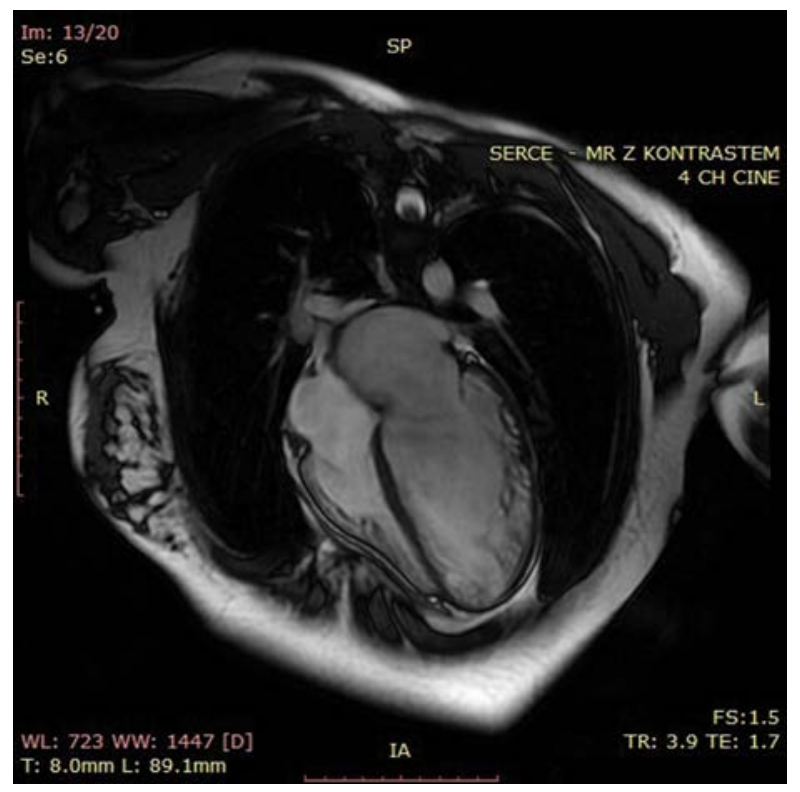

Rycina 3. Obraz serca w badaniu rezonansu magnetycznego tego narządu w trakcie pierwszej hospitalizacji 
W trakcie kolejnej hospitalizacji pacjentka była w dobrym stanie ogólnym, bez dolegliwości. Wykazywała tolerancję wysiłku na poziomie II klasy niewydolności według New York Heart Association (NYHA), bez cech niewydolności krążenia. W kontrolnym badaniu echokardiograficznym obserwowano LVEF $28 \%$ i łagodna/umiarkowaną niedomykalność zastawki mitralnej, bez płynu w jamach opłucnowych. W badaniach laboratoryjnych stwierdzono normalizację stężeń troponiny oraz progresję wartości NT-proBNP (4046 pg/ml). Zmodyfikowano terapię - odstawiono heparynę drobnocząsteczkową, zwiększono dawkę iwabradyny i bursztynianu metoprololu, a ponadto do leczenia włączono małą dawkę ramiprilu.

Kolejna hospitalizacja odbyła się 6 miesięcy po porodzie. Przy przyjęciu obserwowano poprawę wydolności i tolerancji wysiłku (I/II klasa czynnościowa wg NYHA). W kontrolnym badaniu echokardiograficznym obserwowano LVEF $28 \%$ i poprawę niedomykalności zastawki mitralnej (łagodna niedomykalność). Stężenia NT-proBNP obniżyło się do $2246 \mathrm{pg} / \mathrm{ml}$. W badaniu EKG metodą Holtera nie zarejestrowano złożonych form arytmii, a kontrola rytmu pozostawała dobra. Pacjentce zwiększono dawkę bursztynianu metoprololu i ramiprilu oraz zmniejszono dawkę iwabradyny. W kontrolnym badaniu CMR regresja ognisk obrzęku lewej komory okazała się jedynie częściowa. Ze względu na potencjalnie nadal odwracalną przyczynę dysfunkcji lewej komory - utrzymujący się obrzęk miokardium - pacjentce podano podano kolejny wlew dożylny lewosimendanu. Utrzymano dotychczasowe leczenie przewlekłe.

Po 8 miesiącach od zachorowania chora przeszła 4-tygodniowy cykl rehabilitacji kardiologicznej. Obecnie, rok od zachorowania, u opisywanej pacjentki nie występują objawy HF w skali NYHA, LVEF wynosi 45-47\% (EDV/ESV $110 / 58 \mathrm{ml}$, utrzymują się rytm zatokowy około 60/min oraz cechy hipokinezy IVS i ściany dolnej, bez cech niedomykalności mitralnej, powierzchnia lewego przedsionka wynosi $18 \mathrm{~cm}^{2}$, a napływ mitralny $E / A=0,5 / 0,7 \mathrm{~m} / \mathrm{s}, E / E^{\prime}$ 9. Stosowana farmakoterapia obejmuje: bursztynian metoprololu w dawce $2 \times 100 \mathrm{mg}$, iwabradynę w dawce $2 \times$ $2,5 \mathrm{mg}$, ramipril w dawce $2 \times 5 \mathrm{mg}$, furosemid w dawce $40 \mathrm{mg} /$ dobę, eplerenon w dawce $50 \mathrm{mg} /$ dobę, suplementację potasu (przebieg leczenia przedstawiono na ryc. 4).

Pacjentka, której bezwzględnie zakazano zachodzenia w kolejną ciążę, pozostaje pod kontrolą poradni kardiologicznej.

\section{Podsumowanie}

Opisywany przypadek dotyczy piorunującego przebiegu PPCM. Kolejne kroki diagnostyczne i terapeutyczne podejmowano na podstawie dostępnych danych z piśmiennictwa, dostosowując je do stopnia HF oraz stanu klinicznego chorej.

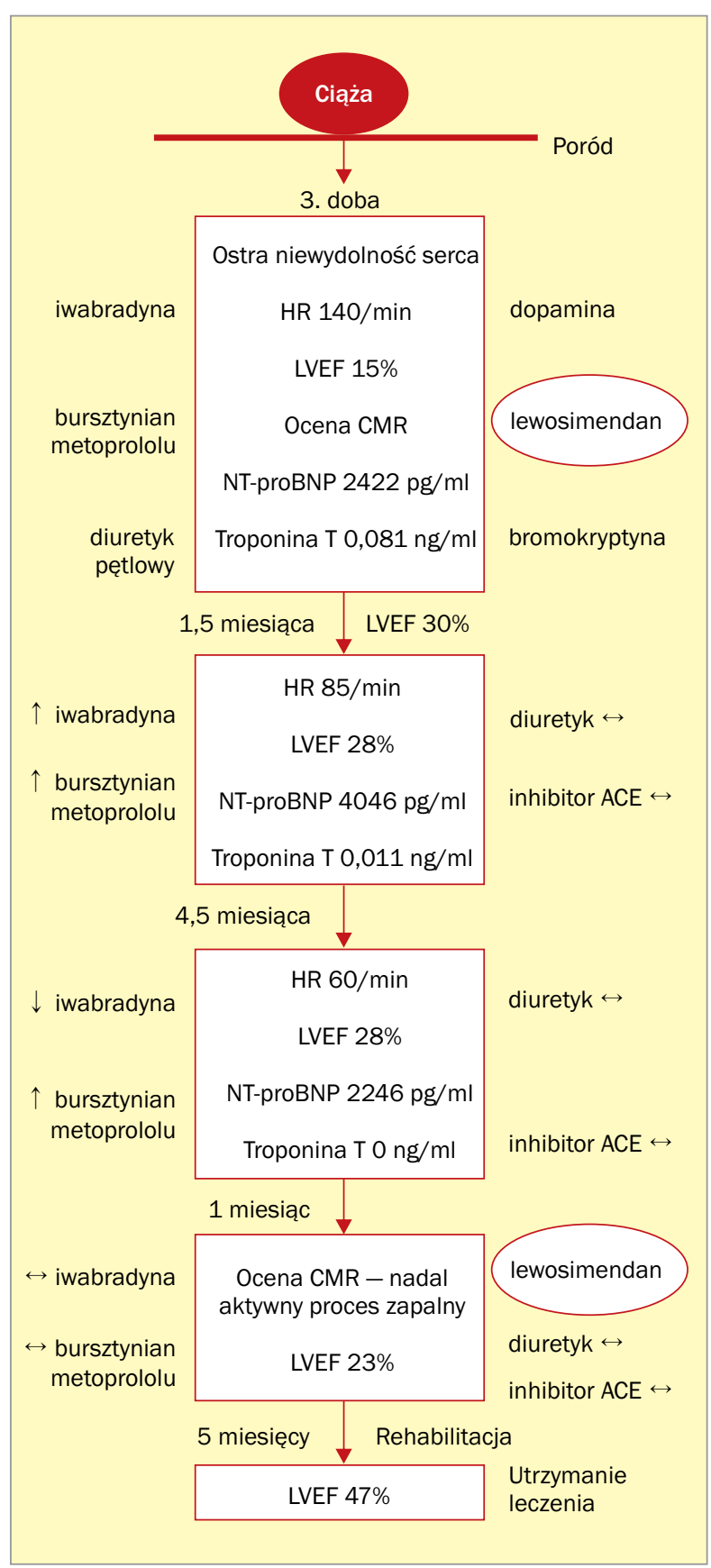

Rycina 4. Przebieg procesu leczenia; HR (heart rate) - tętno; LVEF (left ventricular ejection fraction) - frakcja wyrzutowa lewej komory; CMR (cardiovascular magnetic resonance) - rezonans magnetyczny serca; NT-proBNP (N-terminal B-type natriuretic propeptide) - N-końcowy fragment propeptydu natriuretycznego typu B; ACE (angiotensin-converting enzyme) - konwertaza angiotensyny

Pacjentka wymagała podejmowania pilnych decyzji zależnie od stopnia HF. W początkowym etapie leczenia, ze względu na cechy wstrząsu kardiogennego, zastosowano aminy presyjne. Obserwowano istotną dysfunkcję skurczową lewej komory. Z powodu aktywnego procesu zapalnego, uwidocznionego w CMR, przeciwzakrzepowo stosowano 
heparynę drobnocząsteczkową. W trakcie kolejnych hospitalizacji nadal obserwowano aktywny proces zapalny w miokardium. Dlatego, zważywszy na wciąż potencjalnie odwracalną przyczynę kardiomiopatii, podano kolejny wlew lewosimendanu - leku o działaniach inotropowym oraz naczyniorozszerzającym na mięśniówkę naczyń [6]. W trakcie procesu terapeutycznego pacjentka wymagała modyfikacji terapii, właściwego odwadniania, adekwatnego odciążania lewej komory, każdorazowej oceny wydolności według klasy NYHA. Standardem jest włączenie we wczesnym okresie bromokryptyny. W początkowym okresie leczenia zalecono ograniczenie aktywności fizycznej, a następnie stopniową aktywizację chorej. Modyfikowano dawki beta-adrenolityku w celu uzyskania lepszej kontroli rytmu. Równocześnie, w tym samym celu, stosowano iwabradynę. Chorą poddano kompleksowej rehabilitacji kardiologicznej po około 8 miesiącach od zachorowania. Wstępnie, i jak się okazało słusznie, odraczano decyzję o implantacji wszczepialnego kardiowertera-defibrylatora w ramach prewencji pierwotnej. Obecnie u chorej nie ma wskazań do implantacji. Najistotniejsze w procesie leczenia i w odniesieniu do odwracalności objawów jest pierwsze 6 miesięcy od rozpoznania. Trzeba pamiętać, że potencjalna regresja zmian opisywana w literaturze może nastąpić do 2 lat od zachorowania, ale dotyczy jedynie $50 \%$ chorych.

\section{Konflikt interesów}

Autorzy nie zgłaszają konfliktu interesów.

\section{Abstract}

Peripartum cardiomyopathy (PPCM) is fast extending cardiomyopathy, which is manifested by heart failure in the last month of pregnancy or within 5 months after childbirth. Mortality described in various publications ranges from 7 to $50 \%$. The article describes fast process of PPCM in 25-year-old woman with cardiogenic shock in the initial period, and then a gradual improvement, which requires diagnostic and therapeutic steps.

Key words: eripartum cardiomiopathy, acute circulatory failure, levosimendan

Folia Cardiologica 2017; 12, 5: 489-492

\section{Piśmiennictwo}

1. Elkayam U, Akhter MW, Singh H, et al. Pregnancy-associated cardiomyopathy: clinical characteristics and a comparison between early and late presentation. Circulation. 2005; 111(16): 2050-2055, doi: 10.1161/01.CIR.0000162478.36652.7E, indexed in Pubmed: 15851613.

2. Elliott P, Andersson B, Arbustini E, et al. Classification of the cardiomyopathies: a position statement from the European Society Of Cardiology Working Group on Myocardial and Pericardial Diseases. Eur Heart J. 2008; 29(2): 270-276, doi: 10.1093/eurheartj/ehm342, indexed in Pubmed: 17916581.

3. Desplantie 0, Tremblay-Gravel M, Avram R, et al. BRO-HF Initiative Investigators. The medical treatment of new-onset peripartum cardiomyopathy: a systematic review of prospective studies. Can J Cardiol. 2015; 31(12): 1421-1426, doi: 10.1016/j.cjca.2015.04.029, indexed in Pubmed: 26160409.
4. Bauersachs J, Arrigo M, Hilfiker-Kleiner D, et al. Current management of patients with severe acute peripartum cardiomyopathy: practical guidance from the Heart Failure Association of the European Society of Cardiology Study Group on peripartum cardiomyopathy. Eur J Heart Fail. 2016; 18(9): 1096-1105, doi: 10.1002/ejhf.586, indexed in Pubmed: 27338866.

5. Demakis JG, Rahimtoola SH, Sutton GC, et al. Natural course of peripartum cardiomyopathy. Circulation. 1971; 44(6): 1053-1061, indexed in Pubmed: 4256828.

6. Biteker M, Duran NE, Kaya H, et al. Effect of levosimendan and predictors of recovery in patients with peripartum cardiomyopathy, a randomized clinical trial. Clin Res Cardiol. 2011; 100(7): 571-577, doi: 10.1007/s00392-010-0279-7, indexed in Pubmed: 21197536. 